\title{
CHEMICAL CONSTITUENTS AND TOXICITY OF Agastache foeniculum (PURSH) KUNTZE ESSENTIAL OIL AGAINST TWO STORED-PRODUCT INSECT PESTS
}

\author{
Asgar Ebadollahi* ${ }^{*}$
}

\begin{abstract}
The uncontrolled use of synthetic insecticides is a great hazard for the environment and consumers. Essential oils were introduced as low toxic agents against mammals and non-targeted insects. In this study, essential oil from aerial parts of blue giant hyssop (Agastache foeniculum [Pursh] Kuntze) (Lamiaceae) was isolated by the water steam distillation method with a Clevenger apparatus, and its chemical composition was studied by gas chromatography mass spectrometry. The toxicity of A. foeniculum essential oil against red flour beetle, Tribolium castaneum (Herbst), and lesser grain borer Rhyzopertha dominica (F.) was evaluated by fumigation at 24, 48, and $72 \mathrm{~h}$ exposure times. Estragole and 1,8-cineole were identified as major constituents of the A. foeniculum oil. Fumigation bioassays revealed that $A$. foeniculum oil had strong insecticidal activity on experimental insects. Rhyzopertha dominica was more susceptible than T. castaneum for all exposure times. Insecticidal activity varied with essential oil concentration and exposure time. Probit analysis showed that increased exposure time and essential oil concentration increased mortality. These results indicated that $A$. foeniculum essential oil can be applied in the management of stored-product insects to decrease the detrimental effects of synthetic insecticides.
\end{abstract}

Key words: Blue giant hyssop, fumigation, Rhyzopertha dominica, Tribolium castaneum.

$\mathrm{T}$ he red flour beetle, Tribolium castaneum (Herbst) (Coleoptera: Tenebrionidae), has long been associated with stored food for human consumption and with a wide range of commodities including grain, flour, peas, beans, cacao, nuts, dried fruits, and spices, although milled grain products such as flour appear to be its preferred food. Its presence in stored foods directly affects both the quantity and quality of the commodity (Campbell and Runnion, 2003). The lesser grain borer, Rhyzopertha dominica (F.) (Coleoptera: Bostrichidae), is a destructive insect pest of stored grains. Both larvae and adults of this insect feed on whole, sound grains and cause extensive damage (Dowdy and McGaughey, 1992).

Controlling these insects and other stored-product pests relies heavily on gaseous fumigants. Although effective synthetic insecticides such as methyl bromide or phosphine are available, there is a global concern about their negative effects causing ozone depletion, environmental pollution, toxicity to non-target organisms,

${ }^{1}$ Young Researchers Club, Islamic Azad University, Ardabil branch, P.O. BOX: 467, Ardabil, Iran.

*Corresponding author (Asgar.ebadollahi@gmail.com).

Received: 5 October 2010.

Accepted: 20 December 2010 and pesticide residues (Lee et al., 2004; Isman, 2006). There is an urgent need to develop safe alternatives with the potential to replace toxic fumigants, and still be effective, economical, and convenient. Natural compounds of plant origin are biodegradable, often of low mammalian toxicity, and pose a low danger to the environment if used in small amounts (Papachristos and Stamopoulos, 2002; Ayvaz et al., 2008). There has recently been a growing interest in research as to possibility of using plant extracts as alternatives to synthetic insecticides. Essential oils are complex mixtures comprised of a large number of constituents in variable ratios (Van Zyl et al., 2006). Furthermore, they are volatile and can act as fumigants for stored-product protection. Plant essential oils have had insecticidal (Tapondjou et al., 2002; Negahban et al., 2007; Park et al., 2008), antifungal (Razzaghi-Abyaneh et al., 2008), nematicidal (Oka et al., 2000), virucidal (Schuhmacher et al., 2003), and anti-bacterial (Kotan et al., 2008) effects. This is mainly because essential oils are easily extractable, eco-friendly i.e., biodegradable, easily catabolized in the environment, and do not persist in soil and water (Isman, 2000; 2006). All these properties of essential oils permit their use even in sensitive areas such as schools, restaurants, hospitals, and homes. In spite of the widespread recognition that many plants possess 
insecticidal properties, only a handful of pest control products directly obtained from plants are used because the commercialization of new botanicals can be hindered by a number of issues (Isman, 1997).

Blue giant hyssop, Agastache foeniculum (Pursh) Kuntze, is a species of perennial plant of the mint family (Lamiaceae). It is native to the southwestern and eastern US and central Asia. This flowering plant is very attractive to bees and butterflies and commonly used as garnish for fruit salads, iced tea, desserts, and anise-flavored spices. This species is a candidate for large-scale, domestic cultivation as an aromatic plant with a wide variation in essential oil composition and content (Ayers and Widrlechner, 1994). The Agastache genus has received considerable attention for its variation in essential oil content and composition (Charles et al., 1991).

This paper describes a laboratory study carried out to assess the potential of essential oil as an insecticide. This study investigates fumigant toxicity of the essential oil from aerial parts of $A$. foeniculum against $T$. castaneum and $R$. dominica under laboratory conditions.

\section{MATERIALS AND METHODS}

Plant material, extraction, and analysis of essential oil Aerial parts from $1.5 \mathrm{~cm}$ from the top of A. foeniculum were collected at flowering stage from plants grown on the experimental farm of the Department of Horticulture, University of Urmia, Urmia, Iran. This material was air-dried in the shade at room temperature (26 to 28 ${ }^{\circ} \mathrm{C}$ ) for $14 \mathrm{~d}$. The essential oil was isolated from dried plant samples by hydrodistillation with a Clevengertype apparatus. Extraction conditions were: $50 \mathrm{~g}$ of airdried sample, 1:10 plant material/water volume ratio, 4-h distillation. Anhydrous sodium sulfate was employed to remove water after extraction. Extracted oils were stored in a refrigerator at $4{ }^{\circ} \mathrm{C}$.

The constituents of A. foeniculum essential oil were analyzed by gas chromatography mass spectrometry (GCMS) (Thermo-UFM, Italy). The GC-MS conditions were as follows: capillary column $\mathrm{pH}-5(10 \mathrm{~m} \times 0.1 \mathrm{~mm}$, film thickness $0.4 \mu \mathrm{m})$; helium as carrier gas $\left(0.5 \mathrm{~mL} \mathrm{~min}^{-1}\right)$; oven temperature program initially at $60{ }^{\circ} \mathrm{C}$ rising to 285 ${ }^{\circ} \mathrm{C}$; and injector and detector temperatures of $280^{\circ} \mathrm{C}$. The identification of individual compounds was based on the comparison of their relative retention index with those of original samples on a capillary column (Davies, 1990).

\section{Insects}

Tribolium castaneum was bred in glass containers (1 L) containing wheat (Triticum aestivum $\mathrm{L}$.) flour. The mouth of the containers was covered with a fine mesh cloth for ventilation and to prevent the beetles from escaping.
Rhyzopertha dominica was bred on whole-wheat in similar containers. Cultures were maintained in an incubator at 27 $\pm 2{ }^{\circ} \mathrm{C}$ and $60 \pm 5 \% \mathrm{RH}$ in the dark. Parent adults were obtained from laboratory stock cultures maintained at the Entomology Department, University of Urmia, Iran. Adult insects, 1 to $7 \mathrm{~d}$ old, were used for fumigant toxicity tests. All experimental procedures were carried out under the same environmental conditions as the cultures.

\section{Fumigant bioassay}

The fumigant bioassays were conducted as described by Negahban et al. (2007) with only slight modifications. Concentrations of 10 to $48 \mu \mathrm{L} \mathrm{L}^{-1}$ and 4 to $32 \mu \mathrm{L} \mathrm{L}^{-1}$ of the oil were used for $T$. castaneum and $R$. dominica, respectively. Each concentration was dissolved in 200 $\mu \mathrm{L}$ acetone (solvent) and applied to filter paper strips $\left(4 \times 5 \mathrm{~cm}\right.$, Whatman $\left.\mathrm{N}^{\circ} 1\right)$, which were air-dried for 2 min. Treated filter papers were placed at the bottom of 1-L glass jars. Twenty insect adults were placed in small plastic tubes $(3.5 \mathrm{~cm}$ diameter and $5 \mathrm{~cm}$ height) with open ends covered with cloth mesh. Tubes were hung at the geometrical centre of the glass jars and then sealed with air-tight lids. Thus, there was no direct contact between the oil and the insects. In the control jars, only acetone was applied on the filter papers. Jars were kept in the incubator and mortality was determined after 24,48 , and $72 \mathrm{~h}$ after exposure began. Each experiment was replicated three times for each concentration. Insects were considered dead when no leg or antennal movements were observed.

\section{Statistical analysis}

Mortality percentages were calculated by the Abbott correction formula for natural mortality in the untreated control (Abbott, 1925). To equalize variances, insect mortality percentages were transformed by the squared root of the arcsin. Experiments were arranged in a completely randomized design and data were analyzed by ANOVA. Lethal concentration $\left(\mathrm{LC}_{50}\right.$ and $\left.\mathrm{LC}_{95}\right)$ was estimated by probit analysis whereas lethal time ( $\mathrm{LT}_{50}$ and $\left.\mathrm{LT}_{95}\right)$ values were obtained with SPSS software (SPSS, 2001). The means were separated by the Tukey test at the $5 \%$ level.

\section{RESULTS AND DISCUSSION}

Chemical analysis of the essential oil determined that estragole $(94.003 \%)$ and 1,8-cineole $(3.334 \%)$ were the predominant components (Table 1). Agastache foeniculum oil revealed a strong toxicity against the insects. A $50 \%$ lethal concentration for T. castaneum and $R$. dominica at $24 \mathrm{~h}$ exposure time were 22 and $14 \mu \mathrm{L} \mathrm{L}^{-1}$, respectively. Rhyzopertha dominica was most susceptible and T. castaneum was most tolerant for all exposure times (Table 2A). $\mathrm{LT}_{50}$ values (the time needed to kill $50 \%$ of the 
Table 1. Major chemical constituents of blue giant hyssop (Agastache foeniculum) essential oil and its relative proportions.

\begin{tabular}{lcc}
\hline Component & $\begin{array}{c}\text { Retention } \\
\text { index }\end{array}$ & $\begin{array}{c}\text { Percentage } \\
(\boldsymbol{\%})\end{array}$ \\
\hline 1-Octen-3-ol & 977 & 0.461 \\
3-Octanone & 985 & 0.407 \\
1,8-Cineole & 1058 & 3.334 \\
Octen-3-yl-acetate & 1108 & 0.386 \\
Estragole & 1200 & 94.003 \\
$\alpha-C o p a e n e$ & 1375 & 0.029 \\
$\beta$-Boarbonene & 1386 & 0.084 \\
E-Caryophyllene & 1418 & 0.058 \\
Germacrene D & 1485 & 0.430 \\
Bicyclogermacrene & 1500 & 0.020 \\
Spathulenol & 1570 & 0.039 \\
$\beta$-Eudesmol & 1650 & 0.015 \\
Total & & 99.266 \\
\hline
\end{tabular}

population) were $12.47 \mathrm{~h}$ for $T$. castaneum and $10.05 \mathrm{~h}$ for $R$. dominica at the highest concentrations $\left(42 \mu \mathrm{L} \mathrm{L}^{-1}\right.$ for $T$. castaneum and $32 \mu \mathrm{LL}^{-1}$ for $R$. dominica) (Table $2 \mathrm{~B}$ ). The susceptibility of both insects increased with exposure time and concentration, and $\mathrm{LC}_{50}$ values decreased within $72 \mathrm{~h}$ (Table 2 and Figure 1). On the other hand, the increased susceptibility of the two insects was associated with the increase of the different oil concentrations and exposure time. For example, T. castaneum showed $\mathrm{LC}_{50}=22 \mu \mathrm{L} \mathrm{L}^{-1}$ $24 \mathrm{~h}$ after fumigation, and this value decreased to $13 \mu \mathrm{L}$ $\mathrm{L}^{-1}$ within $72 \mathrm{~h}$.
The most promising botanical groups are Meliaceae, Rutaceae, Asteraceae, Annonaceae, Lamiaceae (e.g. A. foeniculum), Aristolochiaceae, and Malvaceae (RegnaultRoger, 1997). Purple giant hyssop, Agastache rugosa (Fisch. \& C.A. Mey.) Kuntze, essential oil has been evaluated for insecticidal and nematicidal activity (Kim et al., 2003; Choi et al., 2007), and A. foeniculum essential oil indicated strong fumigant toxicity against $T$. castaneum and $R$. dominica in the present study. These insects are from different insect families, thus confirming the wide toxicity range of this essence.

The effect of many essential oils used as insecticides to protect against $T$. castaneum and $R$. dominica infestation has been studied, and these beetles have shown susceptibility to some plant-derived chemicals. Experiments have shown that $T$. castaneum is more tolerant than $R$. dominica. Sahaf et al. (2007) studied fumigant toxicity of Carum copticum C.B. Clarke (Apiaceae) essential oil against Sitophilus oryzae (L.) (Curculionidae) and T. castaneum observing that S.oryzae $\left(\mathrm{LC}_{50}=0.91 \mu \mathrm{L} \mathrm{L}^{-1}\right)$ was significantly more susceptible than $T$. castaneum $\left(\mathrm{LC}_{50}=33.14 \mu \mathrm{L} \mathrm{L}^{-1}\right)$. Chaubey (2007) investigated insecticidal activity of Trachyspermum ammi (L.) Sprague ex Turrill (Apiaceae), Anethum graveolens L. (Apiaceae), and Nigella sativa L. (Ranunculaceae) essential oils against $T$. castaneum. The death of $T$. castaneum adults was caused by fumigation with these essential oils. Fumigant toxicity of Vitex pseudonegundo (Hausskn.) Hand.-Mazz. (Lamiaceae) essential oil against $T$. castaneum and $S$. oryzae was evaluated by Sahaf et al. (2008). They demonstrated that $S$. oryzae $\left(\mathrm{LC}_{50}=\right.$ $31.96 \mu \mathrm{L} \mathrm{L} \mathrm{L}^{-1}$ ) was more susceptible than $T$. castaneum

Table 2. Result of probit analysis to calculate $\mathrm{LC}_{50}, \mathrm{LC}_{95}(\mathrm{~A})$, and $\mathrm{LT}_{50}, \mathrm{LT}_{95}(\mathrm{~B})$ values. $\mathrm{LT}$ values and their corresponding information were calculated at the highest concentrations $\left(42 \mu \mathrm{L} \mathrm{L}^{-1}\right.$ for Tribolium castaneum and $32 \mu \mathrm{L} \mathrm{L}^{-1}$ for Rhyzopertha dominica).

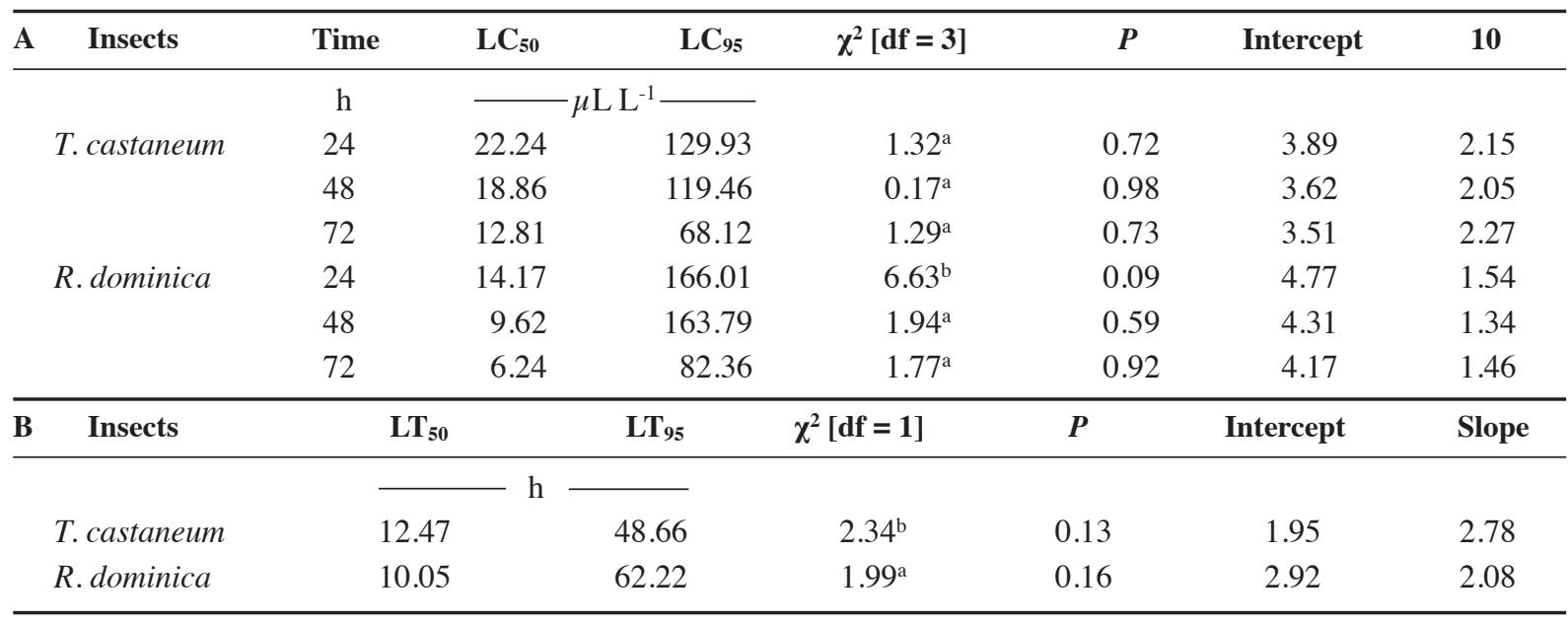

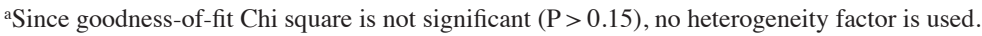

${ }^{\mathrm{b}}$ Since goodness-of-fit Chi square is significant $(\mathrm{P}<0.15)$, a heterogeneity factor is used. 

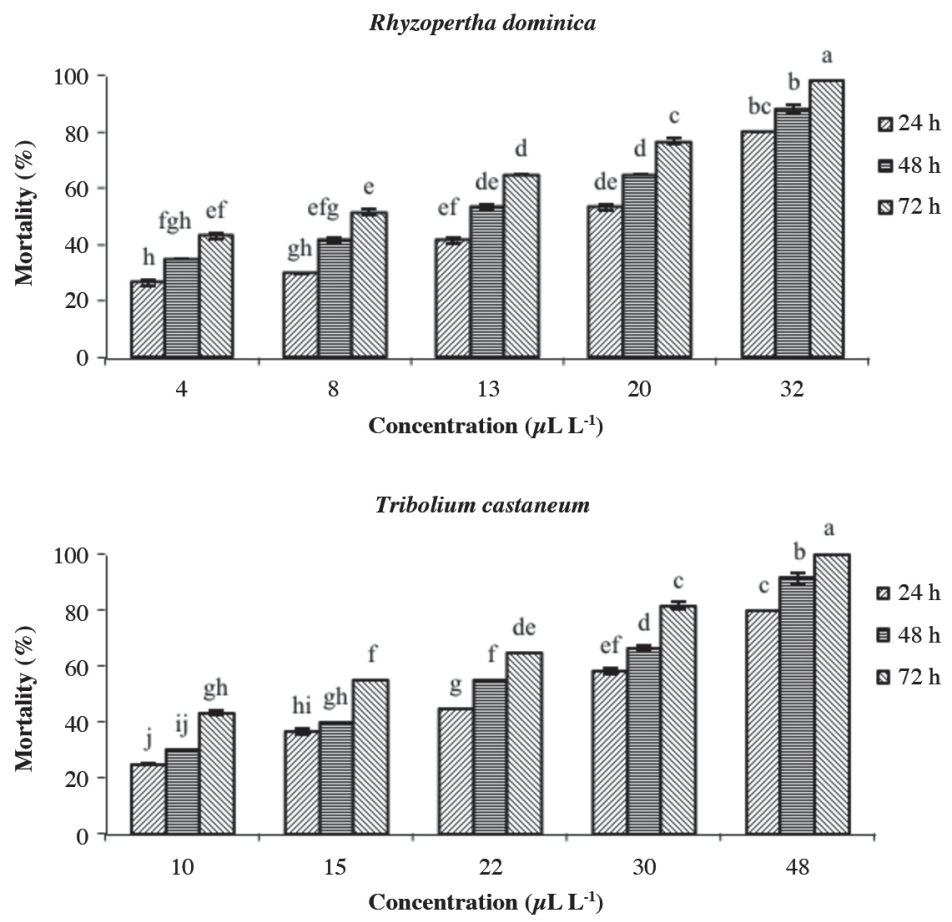

Different letters over columns indicate significant differences according to Tukey test at $\mathrm{p} \leq 0.05$. Columns with the same letter are not significantly different. Vertical bars indicate standard error $( \pm)$; very small values are not represented.

Figure 1. Mean mortality of Rhyzopertha dominica and Tribolium castaneum exposed to different concentrations of Agastache foeniculum essential oil.

$\left(\mathrm{LC}_{50}=47.27 \mu \mathrm{L} \mathrm{L}^{-1}\right)$. Ogendo et al. (2008) found that, except for the more tolerant $T$. castaneum, $\mathrm{LC}_{50}$ values for S. oryzae, R. dominica, Oryzaephilus surinamensis (L.) (Silvanidae), and Callosobruchus chinensis (L.) (Bruchidae) adults ranged from 0.20 to $14 \mathrm{~mL} \mathrm{~L}^{-1}, 0.01$ to $17 \mathrm{~mL} \mathrm{~L}^{-1}$, and 0.80 to $23 \mathrm{~mL} \mathrm{~L}^{-1}$ air $24 \mathrm{~h}$ after treatment with Ocimum gratissimum L. (Lamiaceae) essential oil, eugenol, and $b-(Z)$-ocimene, respectively. In the other experiment, it was found that Lavandula stoechas L. (Lamiaceae) essential oil had insecticidal effects on Lasioderma serricorne (F.) (Anobiidae), R. dominica, and T. castaneum. Lasioderma serricorne $\left(\mathrm{LC}_{50}=3.835 \mu \mathrm{L}\right.$ $\mathrm{L}^{-1}$ ) was significantly more susceptible than $R$. dominica $\left(\mathrm{LC}_{50}=5.66 \mu \mathrm{L} \mathrm{L}^{-1}\right)$ and $T$. castaneum $\left(\mathrm{LC}_{50}=39.685\right.$ $\left.\mu \mathrm{L} \mathrm{L}^{-1}\right) 24 \mathrm{~h}$ after treatment (Ebadollahi et al., 2010). These findings are similar to the results of this study for sensibility of $T$. castaneum and $R$. dominica to plant essential oils and T. castaneum is more tolerant than $R$. dominica.

Previous studies have shown that, in general, the toxicity of plant essential oils against stored-product pests is related to their major components (Isman et al., 2001; Tapondjou et al., 2002; Singh et al., 2003). Estragole (= methyl chavicol) is a major constituent of
A. foeniculum essential oil (Charles et al., 1991; Mazza and Kiehn, 1992), fact which was confirmed in this study. Lopez et al. (2008) reported estragole as an example of toxic fumigant compounds in Coriandrum sativum L. (Apiaceae), Carum carvi L. (Apiaceae), and Ocimum basilicum L. (Lamiaceae) essential oils that are active against insect pests. Another major constituent of $A$. foeniculum oil, 1,8-cineole, is reported as a toxic agent against some insect pests (Tripathi et al., 2001; Yang et al., 2004; Kordali et al., 2006; Stamopoulos et al., 2007).

\section{CONCLUSIONS}

According to the results obtained from the current study and previous studies, it can be suggested that $A$. foeniculum essential oil, or probably its components, can be used to control stored-product insect pests. If costeffective commercial problems are solved, essential oils obtained from plants can be used as part of integrated pest management strategies. Therefore, large quantities of plant material must be processed to obtain sufficient quantities of essential oils for commercial-scale tests, situation which also requires breeding these plants in great quantities. 


\section{ACKNOWLEDGEMENTS}

I would like to thank M.H. Safaralizadeh, A.A. Pourmirza, H.J. Golizadeh, and S.A. Gheibi for their excellent technical support during the experimental work. I am also grateful for the valuable comments provided by an anonymous reviewer.

\section{RESUMEN}

Componentes químicos y toxicidad del aceite esencial de Agastache foeniculum (Pursh) Kuntze contra dos plagas de insectos de productos almacenados. El uso incontrolado de los insecticidas sintéticos causa gran peligro para el medio ambiente y los consumidores. Los aceites esenciales se presentan como agentes tóxicos leves contra mamíferos e insectos no objetivo. En el presente estudio, el aceite esencial de las partes aéreas del hisopo gigante azul (Agastache Foeniculum [Pursh] Kuntze) (Lamiaceae) se aisló por el método de destilación al vapor de agua, utilizando un aparato de Clevenger y se estudió su composición química mediante cromatografía de gases y espectrometría de masas. La toxicidad del aceite esencial de A. foeniculum se evaluó por métodos de fumigación a las 24,48 y 72 h contra el escarabajo rojo de la harina (Tribolium castaneum (Herbst)) y el barrenador menor de granos (Rhyzopertha dominica (F.)). El estragol y 1,8-cineole se detectaron como componentes principales en el aceite A. foeniculum. Los bioensayos revelaron que el aceite de $A$. foeniculum tuvo una fuerte actividad insecticida sobre los insectos experimentales. $R$. dominica fue más susceptible que $T$. castaneum en todos los tiempos. La actividad insecticida varió con las concentraciones de aceite esencial y los tiempos de exposición. El análisis Probit mostró que la mortalidad aumenta con el incremento del tiempo de exposición y la concentración del aceite esencial. Estos resultados indican que el aceite esencial del A.foeniculum podría ser aplicable al manejo de insectos de productos almacenados con el fin de disminuir los efectos perjudiciales de la utilización de insecticidas sintéticos.

Palabras clave: hisopo gigante azul, fumigación, Rhyzopertha dominica, Tribolium castaneum.

\section{LITERATURE CITED}

Abbott, W.S. 1925. A method for computing the effectiveness of an insecticide. Journal of Economic Entomology 18:265-267.

Ayers, G.S., and M.P. Widrlechner. 1994. The genus Agastache as bee forage: a historical perspective. American Bee Journal 134:341-348.
Ayvaz, A., S. Albayrak, and S. Karaborklu. 2008. Gamma radiation sensitivity of the eggs, larvae and pupae of Indian meal moth Plodia interpunctella (Hübner) (Lepidoptera: Pyralidae). Pest Management Science 64:505-512.

Campbell, J.F., and C. Runnion. 2003. Patch exploitation by female red flour beetles, Tribolium castaneum. Journal of Insect Science 3(20):1-8.

Charles, D.J., J.E. Simon, and M.P. Widrlechner. 1991. Characterization of essential oil of Agastache species. Journal of Agricultural and Food Chemistry 39:19461949.

Chaubey, M.K. 2007. Insecticidal activity of Trachyspermum ammi (Umbelliferae), Anethum graveolens (Umbelliferae) and Nigella sativa (Ranunculaceae) essential oils against stored-product beetle Tribolium castaneum Herbst (Coleoptera: Tenebrionidae). African Journal of Agricultural Research 2(11):596-600.

Choi, I.H., J.Y. Park, S.C. Shin, J. Kim, and I.K. Park. 2007. Nematicidal activity of medicinal plant essential oils against the pinewood nematode (Bursaphelenchus xylophilus). Applied Entomology and Zoology 42:397-401.

Davies, N.W. 1990. Gas chromatographic retention indices of monoterpenes of methyl silicones and carbowax $20 \mathrm{~m}$ phases. Journal of Chromatography 503:1-24.

Dowdy, A.K., and W.H. McGaughey. 1992. Fluorescent pigments for marking lesser grain borers (Coleoptera: Bostrichidae). Journal of Economic Entomology 85:567-569.

Ebadollahi, A., M.H. Safaralizadeh, and A.A. Pourmirza. 2010. Fumigant toxicity of Lavandula stoechas L. oil against three insect pests attacking stored products. Journal of Plant Protection Research 50:56-60.

Isman, M.B. 1997. Neem and other botanical insecticides commercialization. Phytoparasitica 25:339-344.

Isman, M.B. 2000. Plant essential oils for pest and disease management. Crop Protection 19:603-608.

Isman, M.B. 2006. Botanical insecticides, deterrents, and repellents in modern agriculture and an increasingly regulated world. Annual Review of Entomology 51:45-66.

Isman, M.B., A.J. Wan, and C.M. Passreiter. 2001. Insecticidal activity of essential oils to the tobacco cutworm, Spodoptera littura. Fitoterapia 72:65-68.

Kim, S.I., J.Y. Roh, D.H. Kim, H.S. Lee, and Y.J. Ahn. 2003. Insecticidal activities of aromatic plant extracts and essential oils against Sitophilus oryzae and Callosobruchus chinensis. Journal of Stored Products Research 39:293-303. 
Kordali, S., I. Aslan, O. Calmasur, and A. Cadir. 2006. Toxicity of essential oils isolated from three Artemisia species and some of their major components to granary weevil, Sitophilus granaries (L.) (Coleoptera: Curculionidae). Industrial Crops and Products 23:162170.

Kotan, R., S. Kordali, A. Cadir, M. Kesdek, Y. Kaya, and H. Kilic. 2008. Antimicrobial and insecticidal activities of essential oil isolated from Turkish Salvia hydrangea DC. ex Benth. Biochemical Systematic and Ecology 36:360-368.

Lee, B.H., P.C. Annis, F. Tumaalii, and W.S. Choi. 2004. Fumigant toxicity of essential oils from the Myrtaceae family and 1,8-cineol against 3 major stored-grain insects. Journal of Stored Products Research 40:553564.

Lopez, M.D., M.J. Jordan, and M.J. Pascual-Villalobos. 2008. Toxic compounds in essential oils of coriander, caraway and basil active against stored rice pests. Journal of Stored Products Research 44:273-278.

Mazza, G., and F.A. Kiehn. 1992. Essential oil of Agastache foeniculum, a potential source of methyl chavicol. Journal of Essential Oil Research 4:295-299.

Negahban, M., S. Moharramipour, and F. Sefidkon. 2007. Fumigant toxicity of essential oil from Artemisia sieberi Besser against three stored-product insects. Journal of Stored Products Research 43:123-128.

Ogendo, J.O., M. Kostyukovsky, U. Ravid, J.C. Matasyoh, A.L. Deng, E.O. Omolo, et al. 2008. Bioactivity of Ocimum gratissimum L. oil and two of its constituents against five insect pests attacking stored food products. Journal of Stored Products Research 44:328-334.

Oka, Y., S. Nacar, E. Putievsky, U. Ravid, Z. Yaniv, and Y. Spiegel. 2000. Nematicidal activity of essential oils and their constituents against the root-knot nematode. Phytopathology 90:710-715.

Papachristos, D.P., and D.C. Stamopoulos. 2002. Repellent, toxic and reproduction inhibitory effects of essential oil vapour on Acanthoscelides obtectus (Say) (Coleoptera: Bruchidae). Journal of Stored Products Research 38:117-128.

Park, I.K., J.N. Kim, Y.S. Lee, S.G. Lee, J. Young, Y.A. Ahn, and S.C. Shin. 2008. Toxicity of plant essential oils and their components against Lycoriella ingenua (Diptera: Sciaridae). Journal of Economic Entomology 101:139-144.

Razzaghi-Abyaneh, M., M. Shams-Ghahfarokhi, T. Yoshinari, M.B. Rezaee, K. Jaimand, H. Nagasawa, and S. Sakuda. 2008. Inhibitory effects of Satureja hortensis L. essential oil on growth and aflatoxin production by Aspergillus parasiticus. International Journal of Food Microbiology 123:228-233.
Regnault-Roger, C. 1997. The potential of botanical essential oils for insect pest control. International Pest Management Review 2:25-34.

Sahaf, B.Z., S. Moharramipour, and M.H. Meshkatalsadat. 2007. Chemical constituents and fumigant toxicity of essential oil from Carum copticum against two stored product beetles. Insect Science 14:213-218.

Sahaf, B.Z., S. Moharramipour, and M.H. Meshkatalsadat. 2008. Fumigant toxicity of essential oil from Vitex pseudo-negundo against Tribolium castaneum (Herbst) and Sitophilus oryzae (L). Journal of AsiaPacific Entomology 11:175-179.

Schuhmacher, A., J. Reichling, and P. Schnitzler. 2003. Virucidal effect of peppermint oil on the enveloped viruses herpes simplex virus type 1 and type 2 in vitro. Phytomedicine 10:504-510.

Singh, G., O.P. Singh, M.P. De-Lampasona, and A.N. Cesar-Catalan. 2003. Studies on essential oils, Part 35: chemical and biocidal investigation on Tagetes erecta leaf volatile oil. Flavour and Fragrance Journal 18:62-65.

SPSS. 2001. SPSS Version 10.0. SPSS Inc., Chicago, Illinois, USA.

Stamopoulos, D.C., P. Damos, and G. Karagianidou. 2007. Bioactivity of five monoterpenoid vapours to Tribolium confusum (du Val) (Coleoptera: Tenebrionidae). Journal of Stored Products Research 43:571-577.

Tapondjou, L.A., C. Adler, H. Bouda, and D.A. Fontem. 2002. Efficacy of powder and essential oil from Chenopodium ambrosioides leaves as post-harvest grain protectants against six stored-product beetles. Journal of Stored Products Research 38:395-402.

Tripathi, A.K., V. Prajapati, K. Aggarwal, and S. Kumar. 2001. Toxicity, feeding deterrence and effect of activity of 1,8-cineole from Artemisia annua on progeny production of Tribolium castaneum (Coleoptera: Tenebrionidae). Journal of Economic Entomology 94:979-983.

Van Zyl, R.L., S.T. Seatlholo, and S.F. van Vuuren. 2006. The biological activities of 20 nature identical essential oil constituents. Journal of Essential Oil Research 18:129-133.

Yang, Y.C., H.C. Choi, W.S. Choi, J.M. Clark, and Y.J. Ahn. 2004. Ovicidal and adulticidal activity of Eucalyptus globulus leaf oil terpenoids against Pediculus humanus capitis (Anoplura: Pediculidae). Journal of Agricultural and Food Chemistry 52:25072511. 